\title{
Investigating the impact of a combined approach of perceived organisational support for strengths use and deficit correction on employee outcomes
}

\begin{tabular}{|c|c|}
\hline $\begin{array}{l}\text { Authors: } \\
\text { Crizelle Els }{ }^{1} \\
\text { Karina Moster } \\
\text { Marianne van }\end{array}$ & $\begin{array}{l}\mathrm{t}^{1} \text { (1) } \\
\text { Woerkom }^{2} \text { (1) }\end{array}$ \\
\hline \multicolumn{2}{|c|}{$\begin{array}{l}\text { Affiliations: } \\
\text { 'WorkWell Research Unit for } \\
\text { Economic and Management, } \\
\text { North-West University, } \\
\text { South Africa }\end{array}$} \\
\hline \multicolumn{2}{|c|}{$\begin{array}{l}{ }^{2} \text { Department of Human } \\
\text { Resource Studies, Tilburg } \\
\text { University, the Netherlands }\end{array}$} \\
\hline \multicolumn{2}{|c|}{$\begin{array}{l}\text { Corresponding author: } \\
\text { Crizelle Els, } \\
\text { crizelle.els@nwu.ac.za }\end{array}$} \\
\hline \multicolumn{2}{|c|}{$\begin{array}{l}\text { Received: } 02 \text { Nov. } 2016 \\
\text { Accepted: } 08 \text { Nov. } 2017 \\
\text { Published: } 28 \text { Mar. } 2018\end{array}$} \\
\hline \multicolumn{2}{|c|}{$\begin{array}{l}\text { How to cite this article: } \\
\text { Els, C., Mostert, K., \& Van } \\
\text { Woerkom, M. (2018). } \\
\text { Investigating the impact of a } \\
\text { combined approach of } \\
\text { perceived organisational } \\
\text { support for strengths use and } \\
\text { deficit correction on } \\
\text { employee outcomes. SA } \\
\text { Journal of Human Resource } \\
\text { Management/SA Tydskrif vir } \\
\text { Menslikehulpbronbestuur, } \\
\text { 16(0), a882. https://doi. } \\
\text { org/10.4102/sajhrm. } \\
\text { v16i0.882 }\end{array}$} \\
\hline \multicolumn{2}{|c|}{$\begin{array}{l}\text { Copyright: } \\
\text { (c) 2018. The Authors. } \\
\text { Licensee: AOSIS. This work } \\
\text { is licensed under the } \\
\text { Creative Commons } \\
\text { Attribution License. }\end{array}$} \\
\hline \multicolumn{2}{|l|}{ Read online: } \\
\hline 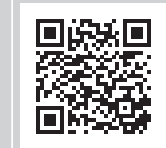 & $\begin{array}{l}\text { Scan this QR } \\
\text { code with your } \\
\text { smart phone or } \\
\text { mobile device } \\
\text { to read online. }\end{array}$ \\
\hline
\end{tabular}

Orientation: The positive psychology paradigm suggests a balanced focus on employee strengths and deficits. However, an overemphasis on strengths has raised questions regarding the value of a focus on strengths use, deficit improvement or a combined approach with a balanced focus on both.

Research purpose: The primary objective was to examine whether perceived organisational support (POS) for strengths use, POS for deficit improvement or a combined approach would be the strongest predictor of work engagement, learning, job satisfaction and turnover intention.

Motivation for the study: In the literature, there is little empirical evidence to support an approach where both employees' strengths are used and their deficits improved.

Research design, approach and method: This study was conducted among 266 teachers from four public schools in the Western Cape. A cross-sectional survey design was used.

Main findings: The results suggest that both strengths use and deficit improvement are important predictors of work engagement, learning, job satisfaction and turnover intention. Learning was higher and turnover intention lower for individuals experiencing a combined approach compared to those believing that their school did not support them in either using their strengths or improving their deficits. Furthermore, a combined approach was associated with higher job satisfaction than a strengths-based approach, and a deficit-based approach was shown to be associated with higher levels of work engagement and lower turnover intentions compared to an environment where neither employees' strengths nor deficits were addressed.

Practical or managerial implications: The results urge organisations to invest an equal amount of resources in their employees' strengths and deficits, as opposed to neglecting either one. Such a combined approach may be associated with increased work engagement, learning and job satisfaction and lower turnover intention.

Contribution: This study provides empirical evidence that supports a combined approach where both employees' strengths are used and their deficits developed.

\section{Introduction}

Scholars in the field of positive psychology are promoting an equal focus on individuals' deficits and strengths (Seligman, 2002; Seligman \& Csikszentmihalyi, 2000). In a work-related context, Van Woerkom Mostert, Els, Bakker and De Beer (2016) argue that employees are dependent on their organisations to support them to improve or develop their deficits and to use their strengths. In their research, Van Woerkom et al. (2016) refer to perceived organisational support (POS) for strengths use to indicate the extent to which employees believe that their organisations are supportive of them applying their strengths in the workplace. Similarly, POS for deficit correction refers to the extent to which employees perceive their organisation as supportive of them in developing their deficits. Although Van Woerkom et al. (2016) and other scholars promote a combined approach, studies usually focus on either strengths or deficits and rarely on a combined approach where both constructs are included.

In the literature it is found that organisations often take a deficit-based approach towards employee development by identifying employee deficits that compromise their performance in a

Note: This article is partially based on the author's thesis for the degree of Philosophiae Doctor in Industrial Psychology at the Potchefstroom Campus of the North-West University, South Africa, with promoter Prof. K. Mostert and co-promoter Dr M. van Woerkom, received October 2015, available here: http://repository.nwu.ac.za/bitstream/handle/10394/15211/Els_C_2015.pdf?isAllowed=y\& sequence $=1$ 
performance appraisal and by providing support in narrowing the gap between actual and desirable performance through training, coaching or feedback (e.g. Carr, 2004; Slade, 2010; Swanson \& Holton, 2001; Wood \& Tarrier, 2010). The focus on deficits or performance problems becomes evident in systematic approaches to human resources development that depart from a needs analysis, in which actual and desired end states are compared (Swanson \& Holton, 2001), or in the competence management approach, in which employees are assessed and developed against a fixed set of competencies (Hall, 2004). Although such a deficit-based approach may indeed lead to considerable performance improvement (Dunn \& Shriner, 1999; Ericsson, Nandagopal \& Roring, 2009; LaFleur \& Hyten, 1995), it does not acknowledge the fact that employees also have strengths, individual characteristics, traits and abilities that, when used, are energising and allow a person to perform at his or her personal best (Linley \& Harrington, 2006; Wood, Linley, Maltby, Kashdan \& Hurling, 2011).

Research has suggested that individuals can greatly benefit from using their strengths, because these refer to tasks for which the individual has an innate ability (Buckingham \& Clifton, 2001). Previous research has found that strengths use is related to higher levels of self-efficacy (Falender \& Shafranske, 2004; Van Woerkom, Oerlemans \& Bakker, 2015b), increased happiness and vitality (Govindji \& Linley, 2007), subjective well-being (Proctor, Maltby \& Linley, 2011), increased work engagement (Harzer \& Ruch, 2012, 2013; Linley \& Harrington, 2006), goal attainment (Linley, Nielsen, Wood, Gillett \& Biswas-Diener, 2010), increased in-role and out-role performance (Van Woerkom \& Meyers, 2015) and lower levels of sick leave (Van Woerkom, Bakker \& Nishii, 2015a). Recently, however, some scholars have objected that the positive psychology movement has again created an imbalance by focusing almost exclusively on employee strengths while failing to pay an equal amount of attention to employee deficits (Rust, Diessner \& Reade, 2009; Sirmon, Hitt, Arregle \& Campbell, 2010).

Thus, from the above arguments, it is suggested that in organisations there seems to be either an overemphasis on employee strengths or on deficits. Previous research, however, has not investigated empirically whether a focus on strengths use, a focus on deficit correction or a combined approach (focusing on both strengths use and deficit correction) may be more advantageous to the organisation. It therefore seems as if organisations are not grasping the possible positive outcomes that a combined approach (considering both strengths use and deficit correction as equally important) may offer. This study aims to address this issue by empirically investigating three possibilities: whether (1) POS for strengths use on its own, (2) POS for deficit correction on its own or (3) a combined approach including both POS for strengths use and POS for deficit correction will best predict employee outcomes, including work engagement, learning, job satisfaction and turnover intention. All these outcomes have been proven to affect the bottom line of the organisation and are therefore important constructs for organisational and individual performance (Bakker \& Bal, 2010; Cropanzano, Rupp \& Byrne, 2003; Judge, Thoresen, Bono \& Patton, 2001; Porath, Spreitzer, Gibson \& Garnett, 2012).

It can also be argued that the teaching profession in particular is in need of a study where the effects of POS for strengths use and POS for deficit correction on employee outcomes are investigated. This profession is typically characterised by high levels of burnout (Johnson, 2015), low work engagement (Buron \& Lassibille, 2016), psychological distress and depression (Domingo et al., 2015), low job satisfaction and high turnover (Shaw \& Newton, 2014; Skaalvik \& Skaalvik, 2011). This clearly illustrates the need to examine whether intervention strategies, namely a strengths-based approach, a deficit-based approach or a combination of the two, may improve outcomes relevant to the teaching profession.

\section{Purpose}

The primary objective of this study was to examine which approach will best predict employee outcomes (i.e. work engagement, learning, job satisfaction and turnover intention): (1) an exclusive focus on POS for strengths use; (2) an exclusive focus on POS for deficit improvement or (3) an approach where both POS for strengths use and POS for deficit correction is combined.

\section{Literature review}

\section{Perceived organisational support for deficit correction and for strengths use}

Perceived organisational support refers to employees' overall beliefs about the extent to which the organisation values their contributions and cares about their well-being (Rhoades, Eisenberger \& Armali, 2001). Although POS for strengths use and deficit correction is related to general POS, the latter construct is much broader. For example, the organisation can also value the employee's contribution by appreciating the fact that the employee is working overtime or care about employees' well-being by encouraging a healthy work-home balance. Employees will perceive organisational support for strengths use when they believe that the organisation actively supports them in applying their strengths at work (Keenan \& Mostert, 2013), for instance by making use of complementary partnering with colleagues or by adapting the task allocation to employees' individual strengths (Linley \& Harrington, 2006). This may implicate that the performance requirements for two individual employees may change, while together they are still responsible for the same tasks, making individual deficits less important for their performance.

Employees will perceive organisational support for deficit correction when they believe that their organisation actively supports them in correcting their deficits. An example of this is when employee deficits that compromise performance are identified in a performance appraisal (Swanson \& Holton, 2001) and when the organisation supports the employee in 
narrowing the gap between the actual and desirable performance by providing training, coaching, feedback or on-the-job learning processes.

Both POS for strengths use and POS for deficit correction may be conceptualised as job resources that are instrumental in achieving organisational and personal work goals, and that may stimulate employees' growth, learning and development (Bakker \& Demerouti, 2007; Van Woerkom et al., 2016). When employees are able to use their unique strengths, they are more likely to achieve performance goals. Also, it is likely that these performance goals will be more self-concordant (Sheldon \& Elliot, 1999) and therefore that employees will be more persistent in achieving these goals (Koestner, Lekes, Powers \& Chicoine, 2002). Moreover, using one's strengths enhances feelings of competence (Peterson \& Seligman, 2004), which will support employees in coping with job demands (Folkman \& Moskowitz, 2004; Van Woerkom et al., 2015a). In addition, furthering one's best skills and abilities leads to steep learning curves, thereby stimulating employee development (Peterson \& Seligman, 2004).

Perceived organisational support for deficit correction may also be seen as a job resource because remediating one's weaknesses facilitates goal attainment and employee development. As workers who feel incompetent report higher levels of stress or burnout (e.g. Brouwers \& Tomic, 2000; Maslach, Schaufeli \& Leiter, 2001), correcting performance deficits by engaging in learning opportunities may reduce job demands, alleviate stress and provide opportunities for growth and development.

\section{Employee outcomes of perceived organisational support for strengths use and for deficit correction}

Following the conceptualisation of POS for strengths use and POS for deficit correction as job resources, these two concepts may be associated with the positive outcomes that are associated with job resources. According to the job demandsresources (JD-R) model, job resources are related to positive outcomes, including work engagement (Bakker \& Demerouti, 2007), learning opportunities (Van Ruysseveldt, Proost \& Verboon, 2011), job satisfaction and the intention to stay with the company (Jones, Chonko, Rangarajan \& Roberts, 2007; Skaalvik \& Skaalvik, 2009).

Work engagement is described as a positive, fulfilling workrelated state that can be characterised by vigour, dedication and absorption (Schaufeli \& Bakker, 2004; Schaufeli, Salanova, González-Romá \& Bakker, 2002). Vigour is characterised by high levels of energy and mental resilience while working, the willingness to invest effort in one's work and persistence even in the face of difficulties (Schaufeli et al., 2002). Dedication refers to being strongly involved in one's work and experiencing a sense of significance, enthusiasm and challenge (Schaufeli et al., 2002). Recent studies suggest that vigour and dedication are the core dimensions of work engagement (Llorens, Schaufeli, Bakker \& Salanova, 2007; Schaufeli \& Bakker, 2004). According to the JD-R theory, job resources are the strongest drivers for work engagement. More specifically, aspects of the job like autonomy, supervisory relationships, opportunities for growth, colleague support, et cetera, greatly influence an employee's levels of work engagement (Bakker, 2011; Bakker \& Bal, 2010). This argument is built on the hypothesis that job resources influence work engagement because of the motivational nature of these resources. It is believed that job resources may play an intrinsic motivational role because they foster growth and learning, or they can play an extrinsic motivational role because they are instrumental in achieving work goals (Bakker \& Demerouti, 2007). Therefore, job resources have a motivational potential and are associated with increased work engagement (Bakker \& Bal, 2010).

It can therefore be expected that the two job resources, POS for strengths use and POS for deficit correction, may lead to increased work engagement. When employees apply their strengths at work and can do what comes naturally to them, they will feel more energised and intrinsically motivated, making them more vigorous and dedicated to their work (Biswas-Diener, 2010). Similarly, when employees feel supported to develop competencies that do not come naturally to them, this may foster their feeling of learning, growth and personal development, which have been found to be associated with work engagement (Bakker, 2011; Mauno, Kinnunen, Mäkikangas \& Feldt, 2010). Within the teaching profession, research has also indicated that support by the school and opportunities for development may increase teachers' work engagement (Bakker \& Bal, 2010). Similarly, it can be argued that when teachers feel competent in what they do and thus experience self-efficacy, they tend to experience higher levels of work engagement (Skaalvik \& Skaalvik, 2014). For these reasons, we expect that both POS for strengths use and POS for deficit correction will increase employees' levels of work engagement.

Learning can be described as the acquisition and application of knowledge and skills and is defined as an important component of thriving (Spreitzer, Sutcliffe, Dutton, Sonenshein \& Grant, 2005). On the one hand, POS for deficit correction can be expected to foster the acquisition of new skills, for example, by providing employees with opportunities for training or coaching. On the other hand, providing employees with the opportunity to use their strengths is likely to lead to the application of knowledge and skills. Also, learning curves tend to be steep when people get the chance to practice their best skills and abilities (Peterson \& Seligman, 2004). This was confirmed in a study by Meyers, Van Woerkom, De Reuver, Bakk and Oberski (2015), who found that both an intervention to promote strengths use and an intervention to promote deficit correction led to increases in students' personal growth initiative, although these increases were bigger for the strengths intervention group.

The extent to which employees feel that their organisation provides them with the desired support to use their strengths 
or remediate their deficits may also influence employees' attitudes regarding their work. When organisations are committed to employee development, employees may feel that they are important to the organisation and may feel more optimistic about the future (Xanthopoulou, Bakker, Demerouti \& Schaufeli, 2007), which may increase their satisfaction with their job and reduce their intention to leave the organisation. Similarly, when employees feel that their work is designed in such a manner that they can do what they are good at, they may find their work more meaningful and may derive more pleasure from their daily activities (Harzer \& Ruch, 2013; Littman-Ovadia \& Steger, 2010). This in turn may influence their satisfaction with their work environment and reduce the risk of them leaving the organisation. Also, using strengths at work and mastering new skills may foster a sense of competence and self-efficacy, making employees feel more in control over their own performance (Bell \& Kozlowski, 2008; Peterson \& Seligman, 2004). This positive attitude may lead to higher levels of job satisfaction and a lower turnover intention. It can therefore be argued that, when teachers feel competent and skilled in what they are doing (i.e. either by means of applying their strengths or by training and learning activities to develop the work-related aspects they are not good at), they are likely to experience stronger job satisfaction and are less likely to want to leave the profession (Høigaard, Giske \& Sundsli, 2012).

Based on the arguments above, it is proposed that both POS for strengths use and POS for deficit correction may be associated with higher levels of work engagement, learning and job satisfaction and lower levels of intention to leave. What we do not know, however, is to what extent one of these approaches is more beneficial than the other, or to what extent a combined approach, focusing on both strengths use and deficit correction, is even more advantageous to the organisation. For this reason we tested three different conceptual models (see Figure 1). In Model A the path from POS for deficit correction was constrained to zero, and the unique contribution of POS for strengths use to each of the outcome variables was examined. In Model B the path from POS for strengths use was constrained to zero, and the unique contribution of POS for deficit correction to each of the outcome variables was examined. Finally, in Model C none of the paths were constrained to zero, and thus the covariance between POS for strengths use and POS for deficit correction were also taken into account.

\section{Research method}

\section{Research approach}

This study followed a quantitative research design and crosssectional data were collected by means of surveys. Therefore, data were collected at one particular point in time (Trochim \& Donnelly, 2007).

\section{Measures}

\section{Participants}

The study population consisted of teachers from public schools in the Western Cape, South Africa. According to the

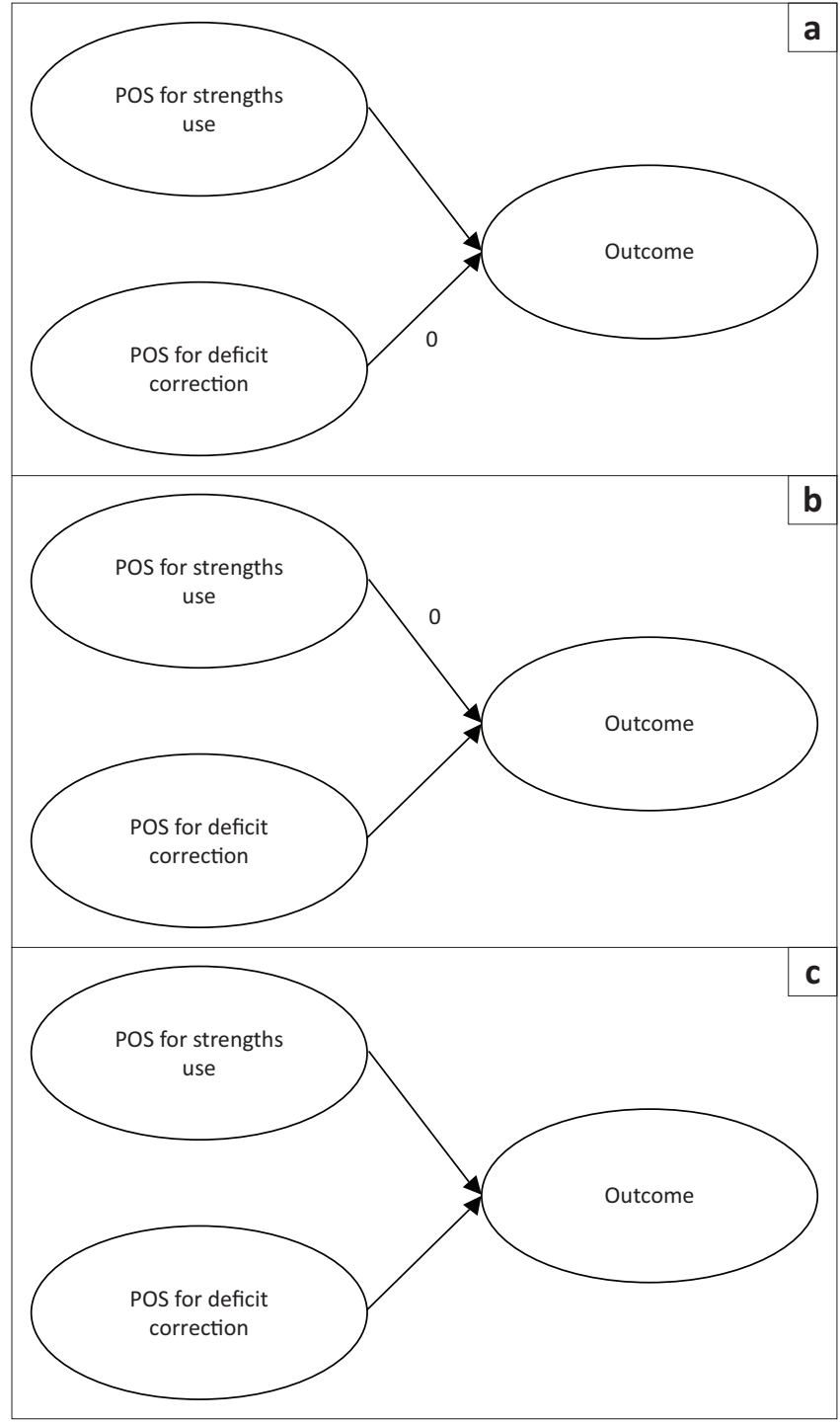

POS, perceived organisational support.

FIGURE 1: Conceptual models. (a) Model A, (b) Model B and (c) Model C.

Department of Basic Education of the Republic of South Africa (2014), there are approximately 11062 educators employed in secondary schools in the Western Cape. A convenient sample of 266 teachers was drawn for the purpose of this study $(n=266)$. The characteristics of the participants are presented in Table 1 . The majority of the sample consisted of females $(64.6 \%)$. The majority were Afrikaans speaking (94.50\%), followed by English speaking (3.7\%). The mean age of the sample was 48.28 years, and almost one-third of the participants $(34.70 \%)$ held a university degree. The majority of the teachers had been with their current school for less than 5 years $(34.20 \%)$.

\section{Measuring instruments}

The strengths use and deficit correction questionnaire (Van Woerkom et al., 2016) was used to measure POS for strengths use and POS for deficit improvement. These constructs were measured on a seven-point Likert-type scale ranging from 0 (never) to 6 (almost always). POS for strengths use was measured with five items (e.g. 'This organisation ensures that people can apply their strong points in their jobs'; $\alpha=0.96$ ) 
and POS for deficit correction was also measured with five items (e.g. 'In this organisation I receive training to improve my weak points'; $\alpha=0.93$ ).

The Utrecht Work Engagement Scale (UWES) was used to measure the two core dimensions of work engagement, namely vigour and dedication (see Schaufeli \& Bakker, 2004). Vigour was measured with six items (e.g. 'At my work, I feel I am bursting with energy') and dedication with five items (e.g. 'I am enthusiastic about my job'). All items were measured on a seven-point frequency-rating scale, varying from 0 (never) to 6 (every day). The reliability for use of the UWES within the South African context has been confirmed with Cronbach's alpha coefficients for vigour $(\alpha=0.78)$ and dedication ( $\alpha=0.89$; Storm \& Rothmann, 2003).

Learning, as a dimension of thriving, was measured with the Thriving at Work Scale developed by Porath et al. (2012). This questionnaire measures learning with five items (e.g. 'I continue to learn more and more as time goes by') on a scale

TABLE 1: Characteristics of participants.

\begin{tabular}{|c|c|c|c|}
\hline Item & Category & Frequency & Percentage \\
\hline \multirow[t]{2}{*}{ Gender } & Male & 87 & 32.10 \\
\hline & Female & 175 & 64.60 \\
\hline \multirow[t]{3}{*}{ Home language } & Afrikaans & 256 & 94.50 \\
\hline & English & 10 & 3.70 \\
\hline & Other & 5 & 1.80 \\
\hline \multirow[t]{6}{*}{ Age } & $16-20$ years & 2 & 0.80 \\
\hline & $21-30$ years & 30 & 11.30 \\
\hline & $31-40$ years & 19 & 7.10 \\
\hline & $41-50$ years & 81 & 30.50 \\
\hline & $51-60$ years & 99 & 37.20 \\
\hline & $60-69$ years & 24 & 9.00 \\
\hline \multirow{7}{*}{$\begin{array}{l}\text { Highest } \\
\text { qualification }\end{array}$} & Grade 10 & 5 & 1.80 \\
\hline & Grade 11 & 0 & 0.00 \\
\hline & Grade 12 & 23 & 8.50 \\
\hline & $\begin{array}{l}\text { Technical College } \\
\text { Diploma }\end{array}$ & 58 & 21.40 \\
\hline & Technicon Diploma & 29 & 10.70 \\
\hline & University Degree & 94 & 34.70 \\
\hline & $\begin{array}{l}\text { Post-graduate } \\
\text { Degree }\end{array}$ & 37 & 13.70 \\
\hline \multirow{6}{*}{$\begin{array}{l}\text { Organisation } \\
\text { tenure }\end{array}$} & $0-5$ years & 91 & 34.20 \\
\hline & $6-10$ years & 35 & 13.20 \\
\hline & $11-20$ years & 51 & 19.20 \\
\hline & $21-30$ years & 52 & 19.50 \\
\hline & $31-40$ years & 24 & 9.00 \\
\hline & $41-50$ years & 3 & 1.10 \\
\hline
\end{tabular}

$N=266$. from 0 (strongly disagree) to 6 (strongly agree). The internal consistency of the instrument was confirmed in previous studies, with Cronbach's alpha coefficients ranging from 0.88 to 0.93 (Porath et al., 2012).

The Job Satisfaction Scale, developed by Hellgren, Sjöberg and Sverke (1997) (based on Brayfield \& Rothe, 1951), was used to examine job satisfaction. This instrument consists of three items (e.g. 'I am satisfied with my job') rated on a Likert scale ranging from 1 (strongly agree) to 5 (strongly disagree). The reliability of this instrument has been confirmed in South Africa ( $\alpha=0.75$; Masia \& Pienaar, 2011).

Turnover intention was measured with a scale developed by Sjöberg and Sverke (2000). The items are measured with a total of three items (e.g. 'I am actively looking for other jobs'). The items are measured on a five-point Likert scale ranging from 1 (strongly agree) to 5 (strongly disagree). This scale has been proven to be reliable within the South African context, with Cronbach's alpha coefficients ranging between 0.74 (Pienaar, Sieberhagen \& Mostert, 2007) and 0.79 (Diedericks \& Rothmann, 2014).

In the current study all scales showed a good internal consistency with Cronbach's alpha coefficients $\geq 0.72$ (see Table 2). Additionally, confirmatory factor analysis including all variables indicated that the overall measurement model showed an acceptable fit to the data $\left(\chi^{2}=1177.00\right.$; $d f=572 ; p=0.00$; comparative fit index $[\mathrm{CFI}]=0.91$; Tucker Lewis index $[\mathrm{TLI}]=0.90$; root-mean-square error of approximation $[\mathrm{RMSEA}]=0.06$; standardised root-meansquare residual $[\mathrm{SRMR}]=0.05)$.

\section{Analysis}

The data were analysed by means of the SPSS program (IBM SPSS Inc., 2009) and Mplus 7.2. Structural equation modelling was used to assess prediction of the dependent variables (employee outcomes) by the independent variables (POS for strengths use and POS for deficit development). The goodness of fit of the models was tested using the traditional $\chi^{2}$ statistic, the CFI, the TLI, the RMSEA and the SRMR. General guidelines were followed and fit was considered adequate if CFI and TLI values were larger than 0.90 (Byrne, 2010). A RMSEA value of 0.05 or less indicates a good fit, whereas values between 0.05 and 0.08 represent a moderately good model fit (Van de Schoot, Lugtig \& Hox, 2012). According to Hu and Bentler (1999), the SRMR value should be smaller than 0.05 . The Akaike information

TABLE 2: Correlation matrix $(r)$ of the latent variables.

\begin{tabular}{|c|c|c|c|c|c|c|c|c|}
\hline Variable & Mean & SD & 1 & 2 & 3 & 4 & 5 & 6 \\
\hline $\begin{array}{l}\text { 1. POS for strengths } \\
\text { use }\end{array}$ & 4.55 & 1.08 & $(0.93)$ & - & - & - & - & - \\
\hline $\begin{array}{l}\text { 2. POS for deficit } \\
\text { correction }\end{array}$ & 3.93 & 1.36 & 0.54 & $(0.92)$ & - & - & - & - \\
\hline 3. Engagement & 5.00 & 0.88 & 0.38 & 0.40 & $(0.92)$ & - & - & - \\
\hline 4. Learning & 4.32 & 0.64 & 0.20 & 0.25 & 0.44 & $(0.72)$ & - & - \\
\hline 5. Job satisfaction & 4.20 & 0.75 & 0.33 & 0.41 & 0.55 & 0.21 & $(0.90)$ & - \\
\hline
\end{tabular}

All correlations are significant at the 0.01 level $(p \leq 0.01) ; r \geq 0.30$ is practically significant (medium effect); $r \geq 0.50$ is practically significant (large effect). Cronbach's alpha coefficients ( $\alpha$ ) are presented on the diagonal in brackets.

Mean, scale means; SD, standard deviation; POS, perceived organisational support. 
criterion and sample adjusted Bayesian information criterion were used to compare the fit of competing models, where the model with the lowest value suggests superior fit (Van de Schoot et al., 2012).

One-way multivariate analysis of variance (MANOVA) was used to assess whether differences exist in work engagement, learning, job satisfaction and turnover intention between different groups (representing different levels of POS for strengths use and POS for deficit correction). The Wilks' lambda statistic was used as an indicator of the significance of group differences (Mayers, 2013). Subsequent analysis of variance (ANOVA) was then conducted to examine the differences for each outcome variable. Where significant differences were found, the Games-Howell post hoc test was used to examine the nature of these differences.

\section{Results}

\section{Relationships between the variables}

The correlations between the study variables are presented in Table 2. The means for the scales (and not the latent variables that were standardised), standard deviations and Cronbach's alpha coefficients of the scales are also presented. All the correlations between all the variables were statistically significant.

\section{Structural equation modelling}

To test whether POS for strengths use and POS for deficit correction were significant predictors of our outcome variables, separate structural models were tested for each of these outcome variables (work engagement, learning, job satisfaction and turnover intention). In all models, both POS for strengths use and POS for deficit correction were included, but three competing models were tested for each outcome variable:

- In Model A, the path from POS for deficit correction to the outcome variable was constrained to zero.

- In Model B, the path from POS for strengths use to the outcome variable was constrained to zero.

- In Model C, paths from both POS for strengths use and POS for deficit correction were specified to the outcome variable (none of the paths in this model were constrained). In addition, a covariance between POS for strengths use and POS for deficit correction was included in the model.

The model fit indices and structural paths for each of the outcome variables are presented in Table 3. As can be seen

TABLE 3: Goodness of fit indices and structural paths investigated for the different outcome variables.

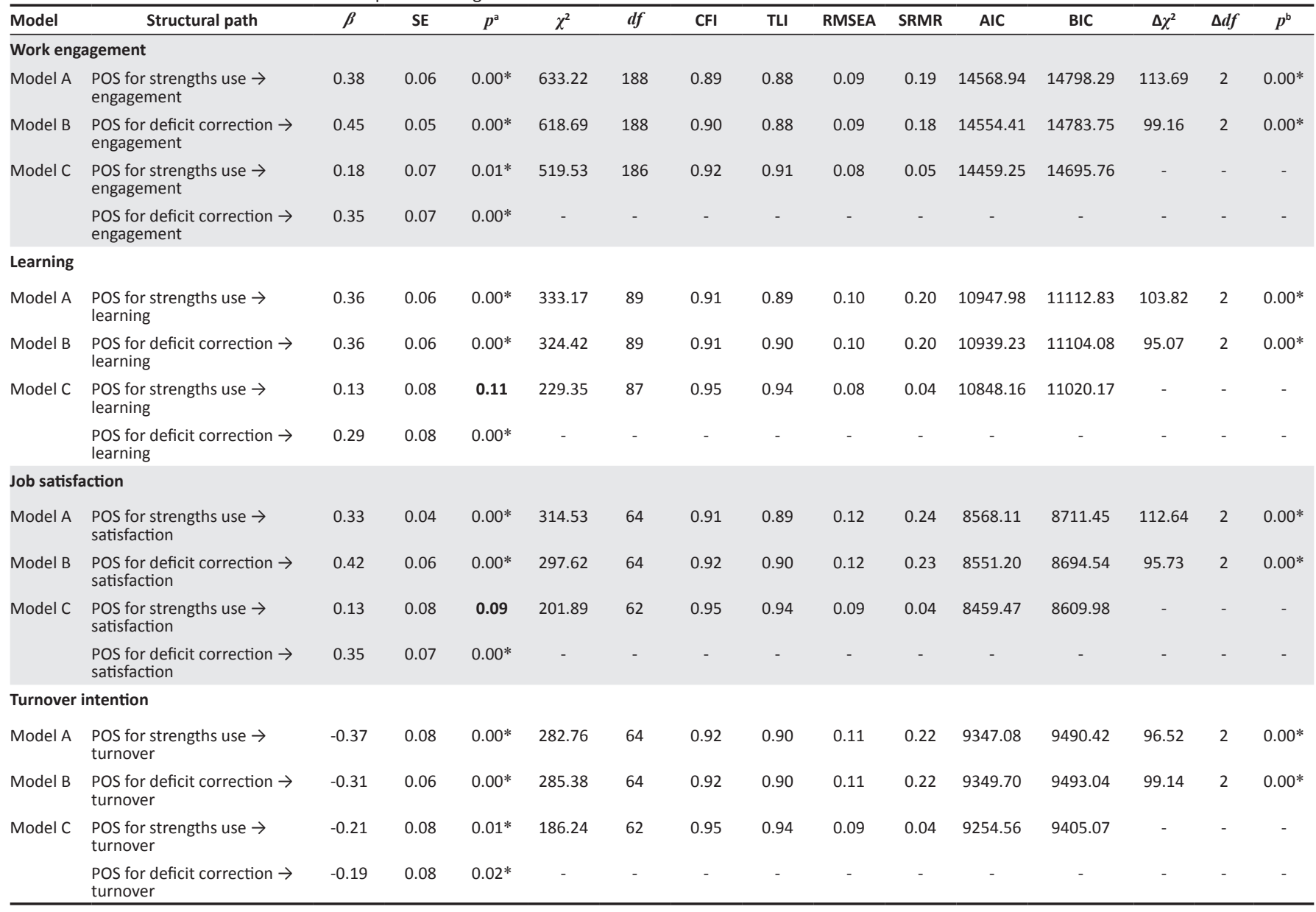

$B$, beta; SE, standard error; a statistical significance of regression paths, values in bold not significant; ${ }^{b}$, statistical significance of chi-squared difference; $\chi^{2}$, chi-squared; $d f$, degrees of freedom; POS, perceived organisational support; CFI, comparative fit index; TLI, Tucker-Lewis index; RMSEA, root-mean-square error of approximation; SRMR, standardised root-mean-square residual; AIC, Akaike information criterion; BIC, Bayesian information criterion.

$*, p \leq 0.01$ 
TABLE 4: Between-group differences based on work engagement, learning, job satisfaction and turnover intention.

\begin{tabular}{lccccccc}
\hline Variable & Group 1: LS_LD & Group 2: HS_LD & Group 3: LS_HD & Group 4: HS_HD & $\boldsymbol{F}$ & \multicolumn{1}{c}{ Partial $\boldsymbol{\eta}^{\mathbf{2}}$} \\
\hline Work engagement & $4.60(0.91)^{\mathrm{a}}$ & $4.98(0.65)$ & $5.14(0.94)^{\mathrm{b}}$ & $5.38(0.72)^{\mathrm{b}}$ & 12.84 & 0.00 \\
Learning & $4.08(0.63)^{\mathrm{a}}$ & $4.30(0.79)$ & $4.35(0.70)$ & $4.47(4.47)^{\mathrm{b}}$ & 5.24 & 0.01 \\
Job satisfaction & $3.93(0.70)^{\mathrm{a}}$ & $4.05(0.83)^{\mathrm{c}}$ & $4.29(0.63)^{\mathrm{b}}$ & $4.55(0.58)^{\mathrm{b}, \mathrm{d}}$ & 12.48 & 0.06 & 0.00 \\
Turnover intention & $2.51(1.04)^{\mathrm{a}}$ & $2.13(0.95)$ & $2.31(0.87)$ & $1.83(0.96)^{\mathrm{b}}$ & 7.02 & 0.13 & 0.00 \\
\hline
\end{tabular}

The means are presented in the table with standard deviations in brackets; statistical significance is set at $p \leq 0.05$.

LS_LD, low POS for strengths use and low POS for deficit correction; HS_LD, high POS for strengths use but low POS for deficit correction; LS_HD, low POS for strengths Use but high POS for deficit correction; HS_HD, high POS for strengths use and high POS for deficit correction.

a, Group differs statistically significantly from type (in row) where $b$ is indicated; ${ }^{c}$, group differs statistically significantly from type (in row) where $d$ is indicated.

from Table 3, Model C was a significantly better model compared to Models A and B for all outcome variables. Also, the results indicate that for work engagement, in Model $C$ both POS for strengths use $(\beta=0.18 ; p \leq 0.01)$ and POS for deficit correction $(\beta=0.35 ; p \leq 0.01)$ were significant predictors of work engagement, with POS for deficit correction being the strongest predictor. With regard to the results for learning, Model C suggests that POS for strengths use was not a significant predictor of learning in the presence of POS for deficit correction. POS for deficit correction, however, significantly predicted learning $(\beta=0.29 ; p \leq 0.01)$. The results for job satisfaction indicate that in Model C, POS for strengths use $(\beta=0.35 ; p \leq 0.00)$ significantly predicted job satisfaction, whereas POS for deficit correction did not significantly predict job satisfaction. The results with regard to turnover intention indicate that in Model C, both POS for strengths use $(\beta=-0.21 ; p \leq 0.01)$ and POS for deficit correction $(\beta=-0.19 ; p \leq 0.05)$ were significant predictors of turnover intention.

The results from Table 3 suggest that for all the employee outcomes (i.e. work engagement, learning, job satisfaction and turnover intention), Model C showed a significantly better fit to the data compared to Models A and B, suggesting that the model where POS for strengths use and POS for deficit correction are combined is a better model compared to the other two models, where only POS for strengths use or POS for deficit correction is included.

\section{Multivariate analysis of variance and analysis of variance}

Multivariate analysis of variance analysis was conducted to compare four different groups of respondents on their levels of work engagement, learning, job satisfaction and turnover intention. The sample was divided into groups based on the mean scores of POS for strengths use and POS for deficit correction, in which responses below the mean were categorised as 'low' and responses above the mean were categorised as 'high'. Consequently, the following four groups were created:

- Group 1 consisted of employees experiencing low POS for strengths use and low POS for deficit correction, implying that the organisation does not provide support for employees in using strengths or developing their weaknesses.

- Group 2 consisted of employees with high POS for strengths use but low POS for deficit correction, implying mainly a strengths-based approach.
- Group 3 consisted of employees with low POS for strengths use but high POS for deficit correction, for example, following mainly a deficit-based approach.

- Group 4 comprised employees experiencing high POS for strengths use and high POS for deficit correction, meaning that these organisations followed a combined approach.

The results of the Wilks' lambda test indicated that statistically significant multivariate group differences were found $\left[F_{(15.657)}=\right.$ 4.14, $p \leq 0.01$; Wilks' $\lambda=0.78$; partial $\left.\eta^{2}=0.08\right]$. The results of the follow-up ANOVA indicated significant differences for each of the five outcomes. Group comparisons were made by means of the Games-Howell procedure, because the group sizes were unequal (Mayers, 2013). The results are presented in Table 4.

The ANOVA results indicate that for all outcome variables, Group 1 (low POS for strengths use; low POS for deficit correction) differed significantly from Group 4 (high POS for strengths use; high POS for deficit correction). In each of these cases the high POS for strengths use and high POS for deficit correction group showed significantly higher levels of work engagement, learning and job satisfaction and lower levels of turnover intention compared to the low POS for strengths use and low POS for deficit correction group. In addition, interesting group differences were found for work engagement and job satisfaction, with results indicating a significant difference between Group 1 (low POS for strengths use; low POS for deficit correction) and Group 3 (low POS for strengths use; high POS for deficit correction), indicating that individuals who believe their organisation provides support to remediate their deficits but does not provide support to use their strengths have significantly higher work engagement and job satisfaction when compared to employees who perceive their organisation as neither using their employees' strengths not correcting their deficits. Similarly, Group 2 (high POS for strengths use; low POS for deficit correction) showed significantly lower job satisfaction levels compared to Group 4 (high POS for strengths use; high POS for deficit correction), suggesting that employees who believe their organisation provides strengths use support but does not help them to improve their deficits reported significantly lower job satisfaction than those employees who indicated that their organisation provides support for both strengths use and deficit correction.

\section{Discussion \\ Outline of the results}

The primary objective of this study was to test three approaches and determine which approach would best 
predict employee outcomes (i.e. work engagement, learning, job satisfaction and turnover intention): (1) an exclusive focus on POS for strengths use; (2) an exclusive focus on POS for deficit improvement or (3) an approach where both POS for strengths use and POS for deficit correction were combined. Our results indicate that both POS for strengths use and POS for deficit correction predict work engagement, learning and job satisfaction and are negatively related to turnover intention. This implies that when employees perceive their organisation to be supportive of them using their strengths or improving their deficits, they are more likely to experience increased levels of work engagement, learning and job satisfaction and lower intentions to leave the organisation. These results are in line with the results from previous research. A recent study by Botha and Mostert (2014) found that employees who are allowed to use their strengths at work experience higher work engagement. Other studies indicate that when individuals are given the opportunity to use their strengths (Falender \& Shafranske, 2004; Peterson \& Seligman, 2004) or master new skills (Bell \& Kozlowski, 2008) these individuals may develop a sense of competence and self-efficacy, giving them the feeling that they have control over their own performance and that they can positively influence their environment. In a work context, such positive attitudes as a result of using one's strengths at work may potentially lead to higher levels of job satisfaction and lower levels of turnover intention. Also, research has shown that in organisations where employees receive opportunities for development, they may feel valued by the organisation (Xanthopoulou et al., 2007), which may influence their job satisfaction. Similarly, employees who feel they apply their strengths at work may feel more optimistic about their job, find their work more meaningful, and may derive more pleasure from their daily activities (Harzer \& Ruch, 2013; Littman-Ovadia \& Steger, 2010), which may influence their job satisfaction. Finally, our study supports advocacy for a combined approach focusing on both individuals' strengths and their deficits, as suggested by leaders in the field of positive psychology. These authors all agree that for optimal human functioning there should be an equal focus on nurturing people's strengths and repairing their weaknesses (Linley, Joseph, Harrington \& Wood, 2006; Rust et al., 2009; Seligman, Parks \& Steen, 2004). It is not surprising that a combined approach yields better employee results compared to an exclusive focus on POS for strengths use or POS for deficit correction. It is reasonable to expect that an organisation that both improves their employees' deficits and uses their strengths may have employees with more positive attitudes towards the organisation, because these employees feel more valued and appreciated by the organisation (Santos \& Stuart, 2003; Xanthopoulou et al., 2007) and enjoy their work more (Harzer \& Ruch, 2013; Schmidt, 2007), because they can do what comes naturally to them and can work on the things that they are less skilled at.

It is worthwhile to note that in our results with learning and job satisfaction as outcome variables, POS for strengths use and POS for deficit correction were both significant predictors of these two outcomes when examined separately. However, when both POS variables were included in one model and the covariance between these two variables was taken into account, the path between POS for strengths use on the one hand and learning and job satisfaction on the other hand became insignificant. Thus, in this study POS for strengths use is a significant predictor of learning and job satisfaction when POS for deficit correction is not accounted for in the model. However, in the case where both strengths use and deficit improvement are present, POS for deficit correction may play the predominant role in increasing learning and job satisfaction, while POS for strengths use may become less significant in predicting these outcomes. A possible explanation for these results may be the nature of our sample, which consisted of secondary school teachers, who may have a predominant orientation on learning and development. Future research needs to explore to what extent these findings can be generalised to other populations. Also, because of our cross-sectional research design, we cannot rule out the possibility that reversed causality played a role in our results. This could mean that engaged and satisfied employees perceive more support for deficit correction compared to other employees, possibly because they have the energy to invest in learning processes that address their weaknesses.

Our results also suggest that for all outcome variables, the high POS for strengths use and high POS for deficit correction group showed significantly higher levels of work engagement, learning and job satisfaction and lower levels of turnover intention compared to the low POS for strengths use and low POS for deficit correction group. It can thus be expected that it will always be better to follow a combined approach of POS for strengths use and POS for deficit correction compared to a lack of support for either strengths use or deficit correction. Our results further indicate that for engagement and job satisfaction an exclusive deficit approach is also more beneficial than an absence of a strengths-based approach or a deficit-based approach. Our results also show that for increased satisfaction a combined approach focusing on both POS for strengths use and POS for deficit correction is better than an exclusive strengths-focused approach. These findings indicate that 'fixing' weaknesses is not by definition demoralising and demeaning (Hodges \& Clifton, 2004) and may even contribute to employee well-being. It is thus strongly suggested that researchers acknowledge the importance of both the use of employees' strengths and the correction of their deficits, rather than overemphasising or neglecting one or the other. Using one's strengths and successfully addressing one's deficits may improve an individual's level of functioning and essentially contribute to a sense of self-actualisation. Self-actualisation is described as being the best an individual is capable of being (Maslow, 1968). Therefore, it is plausible that using one's strengths and also remediating one's deficits gives an individual a sense of competence and the feeling that their potential is realised. Therefore, positive psychology should not just concern itself 
with amplifying strengths but also with supporting people in overcoming their weaknesses (Linley et al., 2006; Seligman et al., 2004).

\section{Practical implications}

Whereas in the past human resource practices were almost exclusively aimed at identifying and correcting employees' weaknesses or deficits, the positive psychology approach has made a case for the importance of employee strengths. Our study can be seen as an investigation of the relative importance of both deficits and strengths-based approaches for promoting employee outcomes such as engagement, learning and satisfaction. The results of our study point out that a combined approach of supporting employees both in leveraging their strengths and remediating their weaknesses leads to the most favourable results in terms of important employee outcomes. Thus, it is demonstrated that, rather than overemphasising or neglecting either strengths use or deficit improvement, organisations are likely to enhance employee outcomes by investing equally in their employees' deficits and their strengths.

\section{Limitations and recommendations}

This study is not without limitations. The cross-sectional design followed cautions the reader to prudently interpret the findings. In order to make sound inferences regarding causal relationships it is suggested that future studies examine these relationships longitudinally. Another limitation in this study was the use of self-report measures, as this threatens the validity of the findings through possible response bias (Bolt \& Johnson, 2009). Although it would be ideal to assess strengths use and deficit improvement of employees with objective measures, this would likely prove to be time and resource intensive.

\section{Conclusion}

To conclude, the results of this study clearly suggest that in an environment where the organisation follows a combined approach - focusing on both POS for strengths use and POS for deficit correction - employees are likely to experience higher levels of work engagement, learning and job satisfaction and lower turnover intention, compared to organisations where neither strengths use nor deficit improvement receive much consideration. Therefore, focusing on both strengths use and deficit improvement may benefit the individual and organisation greatly, indicating the need for employees to both use their strengths and improve their deficits in the work.

\section{Acknowledgements}

We acknowledge the financial assistance of the National Research Foundation (NRF) towards this research. Opinions expressed and conclusions arrived at in the study are those of the authors and do not necessarily reflect the views of the NRF.

\section{Competing interests}

The authors declare that they have no financial or personal relationships that may have inappropriately influenced them in writing this article.

\section{Authors' contributions}

The first author, C.E., fulfilled the role of the primary researcher, and this study formed part of her $\mathrm{PhD}$ research. She was responsible for the conceptualisation of the article, collection and statistical analysis of the data, interpretation of the research results and writing of the article. K.M. acted as promoter and M.v.W. as co-promoter of this study and thus played an advisory role and assisted in the conceptualisation of the study and writing of the research article.

\section{References}

Bakker, A.B. (2011). An evidence-based model of work engagement. Current Directions in Psychological Science, 20(4), 265-269. https://doi.org/10.1177/096372 1411414534

Bakker, A.B., \& Bal, M.P. (2010). Weekly work engagement and performance: A study among starting teachers. Journal of Occupational and Organizational Psychology, 83(1), 189-206. https://doi.org/10.1348/096317909X402596

Bakker, A.B., \& Demerouti, E. (2007). The Job Demands-Resources model: State of the art. Journal of Managerial Psychology, 22(3), 309-328. https://doi.org/10.1108 /02683940710733115

Bell, B.S., \& Kozlowski, S.W. (2008). Active learning: Effects of core training design elements on self-regulatory processes, learning, and adaptability. Journal of Applied Psychology, 93(2), 296-316. https://doi.org/10.1037/0021-9010.93.2.296

Biswas-Diener, R. (2010). Practicing positive psychology coaching: Assessment and strategies for success. Hoboken, NJ: Wiley.

Bolt, D.M., \& Johnson, T.R. (2009). Addressing score bias and differential item functioning due to individual differences in response style. Applied Psychological Measurement, 33(5), 335-352.

Botha, C., \& Mostert, K. (2014). A structural model of job resources, organisational and individual strengths use and work engagement. SA Journal of Industrial Psychology, 40(1), 1-11. https://doi.org/10.4102/sajip.v40i1.1135

Brayfield, A., \& Rothe, H. (1951). An index of job satisfaction. Journal of Applied Psychology, 35(5), 307-311.

Brouwers, A., \& Tomic, W. (2000). A longitudinal study of teacher burnout and perceived self-efficacy in classroom management. Teaching and Teacher perceived self-efficacy in classroom management. Teaching and Teacher

Buckingham, M., \& Clifton, D.O. (2001). Now, discover your strengths. New York: Free Press.

Buron, C.G., \& Lassibille, G. (2016, June). Work engagement among school directors and teachers' behavior at work. In XXV Meeting of the Economics of Education Association. Retrieved July 29, 2016, from http://2016.economicsofeducation. com/user/pdfsesiones/166.pdf

Byrne, B. (2010). Structural equation modeling with AMOS. New York: Routledge.

Carr, A. (2004). Positive psychology: The science of happiness and human strengths. East Sussex, England: Brunner-Routledge.

Cropanzano, R., Rupp, D.E., \& Byrne, Z.S. (2003). The relationship of emotional exhaustion to work attitudes, job performance, and organizational citizenship behaviors. Journal of Applied Psychology, 88(1), 160-169. https://doi.org/ behaviors. Journal of Applied
10.1037/0021-9010.88.1.160

Department of Basic Education of the Republic of South Africa. (2014). Education statistics in South Africa. Retrieved July 29, 2016, from https://www.education. gov.za/Programmes/EMIS/StatisticalPublications.aspx

Diedericks, E., \& Rothmann, S. (2014). Flourishing of information technology professionals: Effects on individual and organisational outcomes. South African Journal of Business Management, 45(1), 27-41.

Domingo, A.K., Asmal, L., Seedat, S., Esterhuizen, T.M., Laurence, C., \& Volmink, J. (2015). Investigating the association between diabetes mellitus, depression and psychological distress in a cohort of South African teachers. South African Medical Journal, 105(12), 1057-1060. https://doi.org/10.7196/SAMJ.2015.v105i12.9843

Dunn, T.G., \& Shriner, C. (1999). Deliberate practice in teaching: What teachers do for self-improvement. Teaching and Teacher Education, 15(6), 631-651. https://doi. org/10.1016/S0742-051X(98)00068-7

Ericsson, K.A., Nandagopal, K., \& Roring, R.W. (2009). Toward a science of exceptional achievement: Attaining superior performance through deliberate practice. In W.C. Bushell, E.L. Olivo, \& N.D. Theise (Eds.), Longevity, regeneration, and optimal health: Integrating Eastern and Western perspectives (vol. 1172, pp. 199-217) Hoboken, NJ: Wiley-Blackwell.

Falender, C.A., \& Shafranske, E.P. (2004). Clinical supervision: A competency-based approach. Washington, DC: American Psychological Association. 
Folkman, S., \& Moskowitz, J.T. (2004). Coping: Pitfalls and promise. Annual Review of Psychology, 55(1), 745-774. https://doi.org/10.1146/annurev.psych.55.090 Po2.141456

Govindji, R., \& Linley, P.A. (2007). Strengths use, self-concordance and well-being: Implications for strengths coaching and coaching psychologists. International Coaching Psychology Review, 2(2), 143-153.

Hall, D.T. (2004). The protean career: A quarter-century journey. Journal of Vocational Behavior, 65(1), 1-13. https://doi.org/10.1016/j.jvb.2003.10.006

Harzer, C., \& Ruch, W. (2012). When the job is a calling: The role of applying one's signature strengths at work. Journal of Positive Psychology, 7(5), 362-371. https:// doi.org/10.1080/17439760.2012.702784

Harzer, C., \& Ruch, W. (2013). The application of signature character strengths and positive experiences at work. Journal of Happiness Studies, 14(3), 965-983. https://doi.org/10.1007/s10902-012-9364-0

Hellgren, J., Sjöberg, A., \& Sverke, M. (1997). Intention to quit: Effects of job satisfaction and job perceptions. In F. Avallone, J. Arnold, \& K. de Witte (Eds.) satisfaction and job perceptions. In F. Avallone, J. Arnold, \&
Feelings work in Europe (pp. 415-423). Milano, Italy: Guerini.

Hodges, T.D., \& Clifton, D.O. (2004). Strengths-based development in practice. In P.A. Lindley \& S. Joseph (Eds.), International handbook of positive psychology in practice: From research to application (pp. 256-268). Hoboken, NJ: Wiley \& Sons.

Høigaard, R., Giske, R., \& Sundsli, K. (2012). Newly qualified teachers' work engagement and teacher efficacy influences on job satisfaction, burnout, and the intention to quit. European Journal of Teacher Education, 35(3), 347-357.

$\mathrm{Hu}$, L., \& Bentler, P.M. (1999). Cut off criteria for fit indexes in covariance structure analysis: Conventional criteria versus structural equation modeling. A Multidisciplinary Journal, 6(1), 1-55. https://doi.org/10.1080/10705519909 540118

IBM SPSS Inc. (2009). SPSS 22.0 [computer software; 2013]. Chicago, IL: SPSS.

Johnson, S.M. (2015). Reducing teacher stress and burnout in high-risk secondary schools in South Africa using transactional analysis. International Journal of schools in South Africa using transactional analysis.
Transactional Analysis Research \& Practice, 6(1), 1-16.

Jones, E., Chonko, L., Rangarajan, D., \& Roberts, J. (2007). The role of overload on job attitudes, turnover intentions, and salesperson performance. Journal of Business Research, 60(7), 663-671. https://doi.org/10.1016/j.jbusres.2007.02.014

Judge, T.A., Thoresen, C.J., Bono, J.E., \& Patton, G.K. (2001). The job satisfaction-job performance relationship: A qualitative and quantitative review. Psychological Bulletin, 127(3), 376-407. https://doi.org/10.1037/0033-2909.127.3.376

Keenan, E.M., \& Mostert, K. (2013). Perceived organisational support for strengths use: The factorial validity and reliability of a new scale in the banking industry. South African Journal of Industrial Psychology, 39(1), 1-12. https://doi. org/10.4102/sajip.v39i1.1052

Koestner, R., Lekes, N., Powers, T.A., \& Chicoine, E. (2002). Attaining personal goals: Self-concordance plus implementation intentions equals success. Journal of Personality and Social Psychology, 83(1), 231-244. https://doi.org/10.1037//0022 3514.83.1.231

LaFleur, T., \& Hyten, C. (1995). Improving the quality of hotel banquet staff performance. Journal of Organisational Behavior Management, 15(1-2), 69-93. https://doi.org/10.1300/J075v15n01_05

Linley, P.A., \& Harrington, S. (2006). Strengths coaching: A potential-guided approach to coaching psychology. International Coaching Psychology Review, 1(1), 37-46.

Linley, P.A., Joseph, S., Harrington, S., \& Wood, A.M. (2006). Positive psychology: Past, present, and (possible) future. The Journal of Positive Psychology, 1, 3-16. https:// present, and (possible) future. The Jour
doi.org/10.1080/17439760500372796

Linley, P.A., Nielsen, K.M., Wood, A.M., Gillett, R., \& Biswas-Diener, R. (2010). Using signature strengths in pursuit of goals: Effects on goal progress, need satisfaction, and well-being, and implications for coaching psychologists. International coaching Psychology Review, 5(1), 6-15.

Littman-Ovadia, H., \& Steger, M. (2010). Character strengths and well-being among volunteers and employees: Toward an integrative model. The Journal of Positive Psychology, 5(6), 419-430. http://doi.org/10.1080/17439760.2010.516765

Llorens, S., Schaufeli, W.B., Bakker, A.B., \& Salanova, M. (2007). Does a positive gain spiral of resources, efficacy beliefs and engagement exist? Computers in Human Behavior, 23(1), 825-841. https://doi.org/10.1016/j.chb.2004.11.012

Masia, U., \& Pienaar, J. (2011). Unravelling safety compliance in the mining industry: Examining the role of work stress, job insecurity, satisfaction and commitment as antecedents. SA Journal of Industrial Psychology, 37(1), 1-10. https://doi. org/10.4102/sajip.v37i1.937

Maslach, C., Schaufeli, W.B., \& Leiter, M.P. (2001). Job burnout. Annual Review of Psychology, 52(1), 397-422. https://doi.org/10.1146/annurev.psych.52.1.397

Maslow, A.H. (1968). Towards a psychology of being (2nd edn.). New York, NY: Van Nostrand.

Mauno, S., Kinnunen, U., Mäkikangas, A., \& Feldt, T. (2010). Job demands and resources as antecedents of work engagement: A qualitative review and suggestions for future research. In S. Albrecth (Ed.), Handbook of employee engagement: Perspectives, issues, research and practice (pp. 111-128). Cheltenham, England: Elgar.

Mayers, A. (2013). Introduction to statistics and SPSS in psychology. London: Pearson.

Meyers, M.C., Van Woerkom, M., De Reuver, R.S.M., Bakk, Z., \& Oberski, D.L. (2015) Enhancing psychological capital and personal growth initiative: Working on strengths or deficiencies. Journal of Counseling Psychology, 62(1), 50-62. https:// doi.org/10.1037/cou0000050

Peterson, C., \& Seligman, M.E.P. (2004). Character strengths and virtues: A handbook and classification. New York: Oxford University Press.
Pienaar, J., Sieberhagen, C.F., \& Mostert, K. (2007). Investigating turnover intentions by role overload, job satisfaction and social support moderation. SA Journal of Industrial Psychology, 33(2), 62-67. https://doi.org/10.4102/sajip. Journal of

Porath, C., Spreitzer, G., Gibson, C., \& Garnett, F. G. (2012). Thriving at work: Toward its measurement, construct validation, and theoretical refinement. Journal of Organizational Behavior, 33(2), 250-275. https://doi.org/10.1002/job.756

Proctor, C., Maltby, J., \& Linley, P.A. (2011). Strengths use as a predictor of well-being and health-related quality of life. Journal of Happiness Studies, 12(1), 153-169. https://doi.org/10.1007/s10902-009-9181-2

Rhoades, L., Eisenberger, R., \& Armali, S. (2001). Affective commitment to the organization: Contribution of perceived organizational support. Journal of Applied Psychology, 86(5), 825-836. https://doi.org/10.1037/0021-9010.86.5.825

Rust, T., Diessner, R., \& Reade, L. (2009). Strengths only or strengths and relative weaknesses? A preliminary study. The Journal of Psychology: Interdisciplinary and Applied, 143(5), 465-476. https://doi.org/10.3200/JRL.143.5.465-476

Santos, A., \& Stuart, M. (2003). Employee perceptions and their influence on training effectiveness. Human Resource Management Journal, 13(1), 27-45. https://doi. org/10.1111/j.1748-8583.2003.tb00082.x

Schaufeli, W.B., \& Bakker, A.B. (2004). Job demands, job resources, and their relationship with burnout and engagement: A multi-sample study. Journal of Organizational Behaviour, 25(3), 293-315. https://doi.org/10.1002/job.248

Schaufeli, W.B., Salanova, M., González-Romá, V., \& Bakker, A.B. (2002). The measurement of engagement and burnout: $A$ two sample confirmatory factor analytic approach. Journal of Happiness Studies, 3(1), 71-92. https://doi. org/10.1023/A:1015630930326

Schmidt, S.W. (2007). The relationship between satisfaction with workplace training and overall job satisfaction. Human Resource Development Quarterly, 18(4), 481-498. https://doi.org/10.1002?hrdq.1216

Seligman, M.E.P. (2002). Authentic happiness: Using the new positive psychology to realize your potential for lasting fulfillment. New York: Free Press.

Seligman, M.E.P., \& Csikszentmihalyi, M. (2000). Positive psychology: An introduction. American Psychologist, 55(1), 5-14. https://doi.org/10.1037//0003-066X.55.1.5

Seligman, M.E.P., Parks, A.C., \& Steen, T. (2004). A balanced psychology and a full life Philosophical Transactions-Royal Society of London Series B Biological Sciences, 359, 1379-1382. https://doi.org/10.1098/rstb.2004.1513

Shaw, J., \& Newton, J. (2014). Teacher retention and satisfaction with a servant leader as principal. Education, 135(1), 101-106.

Sheldon, K.M., \& Elliot, A.J. (1999). Goal striving, need satisfaction, and longitudinal well-being: The self-concordance model. Journal of Personality and Socia Psychology, 76(3), 482-497. https://doi.org/10.1037/0022-3514.76.3.482

Sirmon, D.G., Hitt, M.A., Arregle, J.L., \& Campbell, J.T. (2010). The dynamic interplay of capability strengths and weaknesses: Investigating the bases of temporary competitive advantage. Strategic Management Journal, 31(13), 1386-1409. https://doi.org/10.1002/smj.893

Sjöberg, A., \& Sverke, M. (2000). The interactive effect of job involvement and organizational commitment on job turnover revisited: A note on the mediating role of turnover intention. Scandinavian Journal of Psychology, 41(3), 247-252. https://doi.org/10.1111/1467-9450.00194

Skaalvik, E.M., \& Skaalvik, S. (2009). Does school context matter? Relations with teacher burnout and job satisfaction. Teaching and Teacher Education, 25(3), 518-524. https://doi.org/10.1016/j.tate.2008.12.006

Skaalvik, E.M., \& Skaalvik, S. (2011). Teacher job satisfaction and motivation to leave the teaching profession: Relations with school context, feeling of belonging, and emotional exhaustion. Teaching and Teacher Education, 27(6), 1029-1038. https://doi.org/10.1016/j.tate.2011.04.001

Skaalvik, E.M., \& Skaalvik, S. (2014). Teacher self-efficacy and perceived autonomy: Relations with teacher engagement, job satisfaction, and emotional exhaustion. Psychological Reports, 114(1), 68-77. https://doi.org/10.2466/14.02. PR0.114k14w0

Slade, M. (2010). Mental illness and well-being: The central importance of positive psychology and recovery approaches. BMC Health Services Research, 10(1), 1-14. https://doi.org/10.1186/1472-6963-10-26

Spreitzer, G., Sutcliffe, K., Dutton, J., Sonenshein, S., \& Grant, A.M. (2005). A socially embedded model of thriving at work. Organization Science, 16(5), 537-549. https://doi.org/10.1287/orsc.1050.0153

Storm, K., \& Rothmann, S. (2003). A psychometric analysis of the Utrecht Work Engagement Scale in the South African police service. SA Journal of Industrial Psychology, 29(4), 62-70. https://doi.org/10.4102/sajip.v29i4.129

Swanson, R.A., \& Holton, E.F., III. (2001). Foundations of human resource development. San Francisco, CA: Berret-Koehler.

Trochim, W.M.K., \& Donnelly, J.P. (2007). The research methods knowledge base (3rd edn.). Mason, $\mathrm{OH}$ : Thompson Custom Solutions.

Van de Schoot, R., Lugtig, P., \& Hox, J. (2012). A checklist for testing measurement invariance. European Journal of Developmental Psychology, 9(4), 486-492. https://doi.org/10.1080/17405629.2012.686740

Van Ruysseveldt, J., Proost, K., \& Verboon, P. (2011). The role of work-home interference and workplace learning in the energy-depletion process. Management Revue, 22(2), 151-168. https://doi.org/10.1688/1861-9908

Van Woerkom, M., Bakker, A.B., \& Nishii, L.N. (2015a). Accumulative job demands and support for strength use: Fine-tuning the job demands-resources model using conservation of resources theory. Journal of Applied Psychology, 101(1), 141-150. https://doi.org/10.1037/apl0000033 
Van Woerkom, M., \& Meyers, M.C. (2015). My strengths count! Effects of a strengths-based psychological climate on positive affect and job performance. Human Resource Management, 54(1), 81-103. https://doi.org/10.1002/ hrm.21623

Van Woerkom, M., Mostert, K., Els, C., Bakker, A.B., \& De Beer, L.T. (2016). Strengths use and deficit correction in organizations: Development and validation of a questionnaire. European Journal of Work and Organizational Psychology, 25(6), 960-975. https://doi.org/10.1080/1359432X.2016.1193010

Van Woerkom, M., Oerlemans, W.G.A., \& Bakker, A.B. (2015b). Strengths use and work engagement: A weekly diary study. European Journal of Work and Organisationa Psychology, 25(3), 384-397. https://doi.org/10.1080/1359432X.2015.1089862
Wood, A.M., Linley, P.A., Maltby, J., Kashdan, T.B., \& Hurling, R. (2011). Using personal and psychological strengths leads to increases in well-being over time: A longitudinal study and the development of the strengths use questionnaire. Personality and Individual Differences, 50, 15-19. https://doi.org/10.1016/j. paid.2010.08.004

Wood, A.M., \& Tarrier, N. (2010). Positive clinical psychology: A new vision and strategy for integrated research and practice. Clinical Psychology Review, 30(7), 819-829. https://doi.org/10.1016/j.cpr.2010.06.003

Xanthopoulou, D., Bakker, A.B., Demerouti, E., \& Schaufeli, W.B. (2007). The role of personal resources in the Job Demands-Resources model. International Journal of Stress Management, 14(2), 121-141. https://doi.org/10.1037/1072-5245.14.2.121 